\title{
Formulation of Cinchona Extract (Cinchona succirubra) Cream and the Safety as Hair Fertilizer
}

\author{
Hariyanti*, Retno Wahyuningrum, Shintia L. Charisma \\ Departemen Farmasi, Universitas Muhammadiyah Purwokerto, Jawa tengah, Indonesia
}

Submitted 01 November 2021; Revised 02 November 2021; Accepted 15 November 2021; Published 30 December 2021

*Corresponding author: hariyanti0880@gmail.com

\begin{abstract}
Cinchona extract contains quinoline alkaloids, has telangiectatic activity, is practically insoluble in water so penetration into hair follicles is low, and requires a delivery system, namely cream. Purposed to determine the formula of cinchona extract cream which has good activity, physical stability, and safety. Cinchona bark extraction (soxhletation method), phytochemical screening, cinchona extract dosage determination, optimization of a cream formula using Design-Expert software version 11. Activity test using guinea pigs (Cavia porcellus) and acute dermal irritation test using rabbit (Orycogalus cuniculus). Cinchona extract (13.32\% yield) contained quinoline alkaloids, cinchona extract dosage was $20 \%(\mathrm{p}<0.05)$. The optimum formula on F2 with characteristics: $\mathrm{pH} 6.48 \pm 0.07$, adhesion $1.16 \pm 0.07$, spreadability $4.99 \pm 0.85$, and viscosity $3067 \pm 416.45$ has good physical stability. Activity test: test area hair length $13.54-62.14 \%$ longer than normal control and $10.10-49.17 \%$ than the negative control. The hair mass of the test area was $122.91 \%$ heavier than the normal control and $104.48 \%$ of the negative control $(\mathrm{p}<0.05)$. Cinchona extract and excipients were non-irritant. Cinchona extract cream (20\%) has hair fertilizer activity, good physical stability, and safety.
\end{abstract}

Keywords: Cinchona extract, hair fertilizer, telangiectasia.

\section{Formulasi Krim Ekstrak Kina (Cinchona succirubra) dan Aspek Keamanannya sebagai Penyubur Rambut}

\begin{abstract}
Abstrak
Ekstrak kina mengandung alkaloid quinoline, memiliki aktivitas telangiektasis, praktis tidak larut air sehingga penetrasi ke folikel rambut rendah, dan membutuhkan sistem penghantaran yaitu krim. Bertujuan menentukan formula krim ekstrak kina dengan aktivitas, stabilitas fisik, dan keamanan baik. Ekstraksi kulit kina (metode soxhletasi), skrining fitokimia, penentuan dosis ekstrak kina, optimasi formula krim menggunakan software Design-Expert versi 11. Uji aktivitas menggunakan marmut (Cavia porcellus) dan uji iritasi akut dermal menggunakan kelinci (Orycogalus cuniculus). Ekstrak kina (rendemen 13,32\%) mengandung alkaloid quinoline, dosis ekstrak kina sebagai penyubur rambut $20 \%$ ( $<<0,05)$. Formula optimum pada F2 dengan karakteristik: $\mathrm{pH} 6.48 \pm 0.07$, daya lekat $1.16 \pm 0.07$, daya sebar $4.99 \pm 0.85$, dan viskositas $3067 \pm 416.45$ dengan stabilitas fisik baik. Uji aktivitas: panjang rambut area uji 13,54 - 62,14\% lebih panjang dari kontrol normal dan 10,10 - 49,17\% dari kontrol negatif. Massa rambut area uji 122,91\% lebih berat dari kontrol normal dan 104,48\% dari kontrol negatif $(p<0,05)$. Ekstrak kina dan eksipien bersifat non iritan. Krim ekstrak kina $(20 \%)$ memiliki aktivitas penyubur rambut, stabilitas fisik, dan keamanan baik.
\end{abstract}

Kata Kunci: Ekstrak kina, penyubur rambut, telangiektasis. 


\section{Pendahuluan}

Setiap individu mempunyai impian memiliki rambut yang sehat dan indah, dengan karakteristik rambut tebal, lembut, tidak kering/pecah-pecah, bercahaya dengan sistem perakaran yang kuat. Kerusakan rambut secara umum ditandai dengan rambut yang terlihat kusam, tipis, kasar dan mudah rontok. Kerontokan rambut lebih dari 100 helai/hari menyebabkan terjadinya penurunan densitas rambut dan berdampak pada penurunan kualitas hidup individu. Dalam kondisi tersebut, masyarakat biasanya akan menggunakan produk penyubur rambut dengan bahan aktif sintetik yaitu minoxidil. Minoxidil merupakan penyubur rambut dengan mekanisme vasodilatasi, namun penggunaan jangka panjang dapat meningkatkan resiko efek samping antara lain: iritasi, rasa terbakar pada kulit, udem pada tangan dan kaki, peningkatan bobot badan, pusing, jantung berdebar dan nyeri dada. ${ }^{1-4}$

Ektrak kina dengan kandungan utama alkaloid quinoline (kinin, sinkonin, kuinidin dan sinkonidin) memiliki aktivitas sebagai penyubur rambut dengan mekanisme telangiectasis, yaitu peningkatan vaskularisasi di dermal papila dan folikel rambut dan inhibisi enzim steroid $5 \alpha$-reduktase. Karakteristik ekstrak kina praktis tidak larut dalam air, berdampak pada hidrofobisitas yang tinggi sehingga penetrasi ke dalam dermal papila dan folikel rambut juga rendah. Infundibulum (arco infundibulum) merupakan pintu masuk ke dalam folikel rambut dan dermal papila, dengan karakteristik berupa celah yang menyempit dengan permukaan yang dilapisi oleh stratum korneum. Karakteristik ekstrak kina dan keberadaan infundibulum merupakan tantangan tersendiri bagi formulator dalam mentargetkan sediaan ke dalam folikel rambut dan dermal papilla. ${ }^{4-8}$

Sehingga ekstrak kina membutuhkan suatu sistem penghantaran yang sesuai dan mampu memfasilitasi untuk mencapai folikel rambut dan dermal papila yaitu dengan krim. Krim merupakan sediaan semipadat, sistem 2 fase, sistem emulsi dimana terdapat fase lipid terdispersi dalam fase air atau sebaliknya dengan bantuan emulgator sebagai stabilizer. Krim memiliki keunggulan antara lain mampu memfasilitasi bahan aktif hidrofilik dan atau lipofilik, meningkatkan penetrasi bahan aktif secara transepidermal dan intrafolikular. ${ }^{4-8}$

\section{Metode}

2.1. Alat

Soklet (Iwake Pyrex), cawan porselin, Batang pengaduk, wather Bath (HWB3F-27L), kertas whatman, vacum rotary evaporator, Sendok Sungu, cawan persolin, homogenizer, timbangan analitik, $\mathrm{pH}$ meter ohaus ST3100, viskometer Brookfield DV2T, plat kaca, labu alas bulat, alat-alat gelas.

\subsection{Bahan}

Serbuk kulit batang kina (PT.SIL), etanol (Merk), metil dan propil paraben, vaselin album, paraffin cair, isopropil miristat, gliserin, asam stearat, gliseril monostearat, TEA, xanthan gum, pengaroma coklat, aqua.

\subsection{Hewan Uji}

Uji iritasi dengan kelinci jenis Orycogalus cuniculus berjenis kelamin jantan dan uji aktivitas dengan marmut jenis Cavia porcellus berjenis kelamin jantan. Uji in vivo disetujui oleh Komisi Etik Fakultas Ilmu Kesehatan, Universitas Muhammadiyah Purwokerto.

\subsection{Prosedur Penelitian}

\subsubsection{Ekstraksi Kulit Batang Kina}

Kulit batang kina diekstraksi menggunakan metode soxhletasi. Simplisia kulit kina (50 g) dibungkus dengan kertas saring, dimasukan dalam alat sokhlet ditambahkan etanol $96 \%(300 \mathrm{~mL})$ diekstraksi dengan suhu $50-60^{\circ} \mathrm{C} .{ }^{9}$

\subsubsection{Skrining Fitokimia Ekstrak Kina}

Skrining fitokimia ekstrak kina dilakukan secara kualitatif dengan menggunakan reagen meyer LP, Dragendorff dan Wagner. Parameter pengamatan adalah terbentuknya endapan yang dibandingkan terhadap baku pembanding yaitu kinin, sinkonin, kuinidin dan sinkonidin. ${ }^{9}$ 


\subsubsection{Optimasi Konsentrasi Optimum}

Ekstrak Kulit Kina

Hewan uji dicukur menggunakan gunting dan pisau cukur. Kemudian diaplikasikan krim depilatory agar sisa rambut bersih. ditentukan area perlakuan sebanyak 7 buah dengan masing-masing luas kotak adalah $4 \mathrm{~cm}^{2}(2 \times 2 \mathrm{~cm})$ dan setiap kotak diberi jarak 1 $\mathrm{cm}$. Masing-masing area diaplikasikan sedian uji dengan variasi konsentrasi ekstrak kina 5, $10,15,20,25 \%$, dan area kontrol normal (tidak mendapat perlakuan) dan kontrol negatif (diaplikasikan etanol 70\%) disertai pemijatan ringan (3 menit). Pengamatan dilakukan selama 14 hari terhadap panjang rambut (10 helai rambut) diambil 6 helai terpanjang, diukur menggunakan jangka sorong setiap 2 hari sekali. Kemudian pengukuran massa rambut dilakukan pada hari ke 14. Hasil yang diperoleh dianalisis secara statistik. ${ }^{1-4}$

\subsubsection{Formulasi Krim Ekstrak Kina (Design- Expert versi 11)}

Variasi Formula krim ekstrak kina yang diperoleh dari design expert versi 11 dapat dilihat pada Tabel 1.

\subsubsection{Evaluasi Fisik Krim Ekstrak Kina}

Evaluasi fisik meliputi $\mathrm{pH}$, daya lekat, daya sebar dan viskositas. Dengan parameter uji pH 4,5-6,5; daya lekat 4 detik; daya sebar $5-7 \mathrm{~cm}$, dan viskositas: $2000-50000 \mathrm{cP}$.
2.4.6. Uji Stabilitas Fisik Krim Ekstrak Kina

Uji stabilitas fisik dilakukan dengan metode cycling test. Sediaan dipapar suhu ekstrim bergantian selama 6 siklus (1 siklus 24 jam, di suhu dingin $4^{\circ} \mathrm{C}$ dan suhu panas $40^{\circ} \mathrm{C}$ ). Dilakukan evaluasi terhadap perubahan $\mathrm{pH}$, daya lekat, daya sebar dan viskositas sediaan per siklus. ${ }^{10}$

\subsubsection{Uji Aktivitas Krim Ekstrak Kina}

Hewan uji dicukur menggunakan gunting dan pisau cukur. Kemudian diaplikasikan krim depilatory agar sisa rambut bersih. ditentukan area perlakuan sebanyak 6 buah dengan masing-masing luas kotak adalah $4 \mathrm{~cm}^{2}(2 \times 2 \mathrm{~cm})$ dan setiap kotak diberi jarak $1 \mathrm{~cm}$. Masing-masing area diaplikasikan sedian uji krim ekstrak kina 20\% dan area kontrol normal (tidak mendapat perlakuan) dan kontrol negatif (diaplikasikan basis krim) disertai pemijatan ringan (3 menit). Pengamatan dilakukan selama 14 hari terhadap panjang rambut (10 helai rambut) diambil 6 helai terpanjang, diukur menggunakan jangka sorong setiap 2 hari sekali. Pengukuran massa rambut dilakukan pada hari ke 14. Hasil yang diperoleh dianalisis secara statik. ${ }^{1-4}$

\subsubsection{Uji Iritasi Akut Dermal Krim Ekstrak Kina \\ Punggung kelinci dicukur dengan} lebar kira-kira $10 \times 15 \mathrm{~cm}$ atau tidak kurang

Table 1. Formula krim ekstrak kina design expert versi 11

\begin{tabular}{ccccccccc}
\hline Bahan & F1 & F2 & F3 & F4 & F5 & F6 & F7 & F8 \\
\hline Ekstrak kina & $20 \%$ & $20 \%$ & $20 \%$ & $20 \%$ & $20 \%$ & $20 \%$ & $20 \%$ & $20 \%$ \\
Vaselin & 6,2 & 6,2 & 6,2 & 6,2 & 6,2 & 6,2 & 6,2 & 6,2 \\
Gliserin & 23,5 & 10,5 & 17 & 4 & 30 & 17 & 4 & 30 \\
Paraffin cair & 10,5 & 23,5 & 17 & 30 & 4 & 17 & 30 & 4 \\
Isopropyl Miristat & 1,5 & 1,5 & 1,5 & 1,5 & 1,5 & 1,5 & 1,5 & 1,5 \\
Asam stearate & 7,5 & 7,5 & 7,5 & 7,5 & 7,5 & 7,5 & 7,5 & 7,5 \\
Gliseril Monostearat & 5 & 5 & 5 & 5 & 5 & 5 & 5 & 5 \\
Metil paraben & 0,18 & 0,18 & 0,18 & 0,18 & 0,18 & 0,18 & 0,18 & 0,18 \\
Propil paraben & 0,02 & 0,02 & 0,02 & 0,02 & 0,02 & 0,02 & 0,02 & 0,02 \\
TEA & 0,2 & 0,2 & 0,2 & 0,2 & 0,2 & 0,2 & 0,2 & 0,2 \\
Xanthan gum & 0,2 & 0,2 & 0,2 & 0,2 & 0,2 & 0,2 & 0,2 & 0,2 \\
Pengaroma Coklat & 5 tetes & 5 tetes & 5 tetes & 5 tetes & 5 tetes & 5 tetes & 5 tetes & 5 tetes \\
Aquadest ad & 100 & 100 & 100 & 100 & 100 & 100 & 100 & 100 \\
\hline
\end{tabular}


10\% dibagi menjadi 3 area (area uji, kontrol normal dan kontrol negatif masing-masing $2 \times 3 \mathrm{~cm})$. Masing-masing area diaplikasikan sediaan uji krim ekstrak kina 20\% (0,5 g), dan area kontrol normal (tidak mendapat perlakuan) dan kontrol negatif (diaplikasikan basis krim $0,5 \mathrm{~g}$ ) disertai pemijatan ringan 3 menit. Kemudian ditutup dengan kassa dan direkatkan dengan plester non-iritan. Setelah 4 jam, residu sediaan uji dibersihkan dari kulit dengan air. Dilakukan pengamatan dan perhitungan terhadap indeks eritema dan udema dengan interval waktu 1, 24, 48, dan 72 jam setelah pembukaan plester. Pengamatan dilanjutkan sampai hari ke 14 untuk melihat reversibilitas kulit. ${ }^{15}$

\section{Hasil}

Diperoleh ekstrak kina dengan rendemen 13,32\%. Skrining fitokimia: ekstrak kina mengandung alkaloid, flavonoid dan fenolik. Konsentrasi ekstrak kina optimum sebagai penyubur rambut adalah $20 \% \mathrm{~b} / \mathrm{v}(\mathrm{p}<0,05)$. Evaluasi fisik sediaan krim diperoleh sediaan optimum dengan $\mathrm{pH} 6.48 \pm 0.07$, daya lekat $1.16 \pm 0.07$, daya sebar $4.99 \pm 0.85$ dan viskositas $3067 \pm 416.45$, Uji stabilitas cycling test krim ekstrak kina menunjukkan stabilitas fisik yang baik. Uji aktivitas krim ekstrak kina menunjukkan panjang rambut area uji 13,54 - 62,14\% lebih panjang dari kontrol normal dan 10,10 - 49,17\% lebih panjang dari kontrol negatif. Massa rambut area uji $122,91 \%$ lebih berat dibandingkan kontrol normal dan 104,48\% lebih berat dibandingkan kontrol negatif $(p<0,05)$. Uji iritasi akut dermal menyatakan bahwa ekstrak kina dan eksipien bersifat non iritan dengan indeks eritema dan udema adalah 0 .

\section{Pembahasan}

Ekstraksi merupakan proses pemisahan senyawa dari campuran menggunakan pelarut yang sesuai. Pemilihan pelarut didasarkan pada prinsip "like dissolves like". Karakteristik senyawa target menjadi salah satu pertimbangan penting dalam memilih pelarut untuk memaksimalkan proses ekstraksi. Alkaloid quinolie memiliki hidrofobisitas yang cukup tinggi, sehingga pemilihan pelarut universal (etanol 96\%) dengan rentang kelarutan yang cukup lebar dapat memaksimalkan proses ekstraksi dengan toksisitas yang relatif lebih rendah jika dibandingkan pelarut non polar lainnya. Dalam proses ekstraksi diperoleh ekstrak kina dengan rendemen $13.32 \%$ dimana nilai rendemen akan berbanding lurus dengan total senyawa aktif yang terekstraksi. Dari skrining fitokimia menunjukkan bahwa ekstrak kina mengandung komponen utama alkaloid quinoline yaitu kinin, kuinidin, sinkonin dan sinkonidin yang ditandai dengan terbentuknya endapan dibandingkan terhadap baku pembanding.

Dari Gambar 1 menunjukkan bahwa konsentrasi ekstrak kina sebagai penyubur rambut optimum adalah 20\%. Panjang rambut area yang diaplikasikan ekstrak kina 20\% menunjukkanaktivitas yangberbedasignifikan dibandingkan terhadap kontrol normal, kontrol negatif dan variasi konsentrasi ekstrak

\section{Optimasi konsentrasi ekstrak kina}

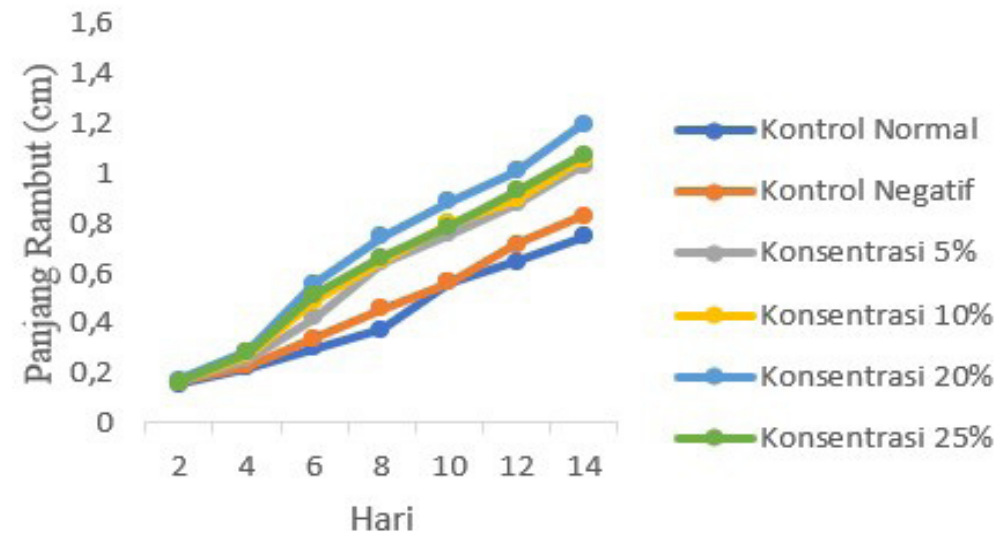

Gambar 1. Optimasi konsentrasi ekstrak kina sebagai penyubur rambut (panjang rambut) 
kina yang lain $(\mathrm{p}<0.05)$. Panjang rambut area kontrol negatif lebih panjang dibandingkan terhadap kontrol normal, hal ini disebabkan karena aplikasi etanol 70\% memiliki efek vasodilatasi pembuluh darah, namun aplikasi jangka panjang dapat meningkatkan resiko terjadinya iritasi. Pada hari ke 14, massa rambut pada area yang diaplikasi ekstrak kina 20\% mengalami peningkatan yang berbeda signifikan dibandingkan terhadap area kontrol $(\mathrm{p}<0.05)$. Pertambahan panjang rambut dan massa rambut disebabkan karena efek telangiektasis, yaitu satu mekaniesme peningkatan vaskularisasi di dermal papila dan folikel rambut. Peningkatan massa rambut kemungkinan disebabkan karena terjadinya peningkatan jumlah folikel rambut atau terjadi peningkatan diameter rambut. Peningkatan vaskularisasi di dermal papila dan folikel rambut berperan penting dalam suplai nutrisi dan $\mathrm{O} 2$ untuk proses pertumbuhan dan regenerasi rambut. ${ }^{4}$

Optimasi formula krim ekstrak kina menggunakan Design Expert versi 11 dengan optimasasi konsentrasi gliserin dan paraffin cair. Kedua bahan ini memiliki peranan yang penting dalam stabilitas fisik krim antara lain menghambat terjadinya penguapan atau keluarnya air dari dalam sistem krim dan sebagai emolien. Paraffin cair sebagai emolien dapat menjaga kelembaban kulit dengan mekanisme menghambat proses TEWL (Trans Epidermal Water Loss) sehingga mampu mempertahankan kadar air dalam kulit. Kondisi kulit yang lembab (kadar air $\pm 10 \%$ ) dapat memfasilitasi atau meningkatkan penetrasi bahan aktif melalui rute transepidermal (interseluler dan transeluler). ${ }^{14}$ Evaluasi fisik sediaan menunjukkan bahwa formula F2 merupakan formula optimum yang ditunjukkan dengan data evaluasi $\mathrm{pH} 6.48 \pm 0.07$; daya lekat $1.16 \pm 0.07$; daya sebar $4.99 \pm 0.85$ dan viskositas $3067 \pm 416.45$ yang memenuhi kriteria krim yang baik. Data ini linier dengan hasil yang diperoleh dari Design Expert versi 11 dimana formula F2 merupakan formula optimum dengan nilai desirability 0,619 (nilai optimum 1). Respon terhadap kombinasi variasi konsentrasi gliserin dan paraffin cair ditunjukkan pada Gambar 2.

Uji stabilitas cycling test bertujuan untuk melihat stabilitas fisik sediaan krim ekstrak kina 20\% terhadap paparan suhu yang ektrim. Dari Gambar 3 dan Gambar 4 menunjukkan bahwa terjadi fluktuasi baik $\mathrm{pH}$, daya lekat, daya sebar dan viskositas, namun masih berada dalam rentang yang diperbolehkan (memenuhi kriteria sediaan krim yang baik). Sehingga dapat disimpulkan bahwa sediaan krim ekstrak kina 20\% memiliki stabilitas fisik yang cukup baik. ${ }^{16}$

Uji aktivitas krim ekstrak kina 20\% pada Gambar 5 menunjukkan terjadinya peningkatan panjang rambut yang berbeda signifikan antara area uji sebesar 13,54 $62,14 \%$ lebih panjang dari area kontrol normal dan 10,10-49,17\% lebih panjang dari area kontrol negatif. Massa rambut di hari ke 14 menunjukkan peningkatan massa rambut
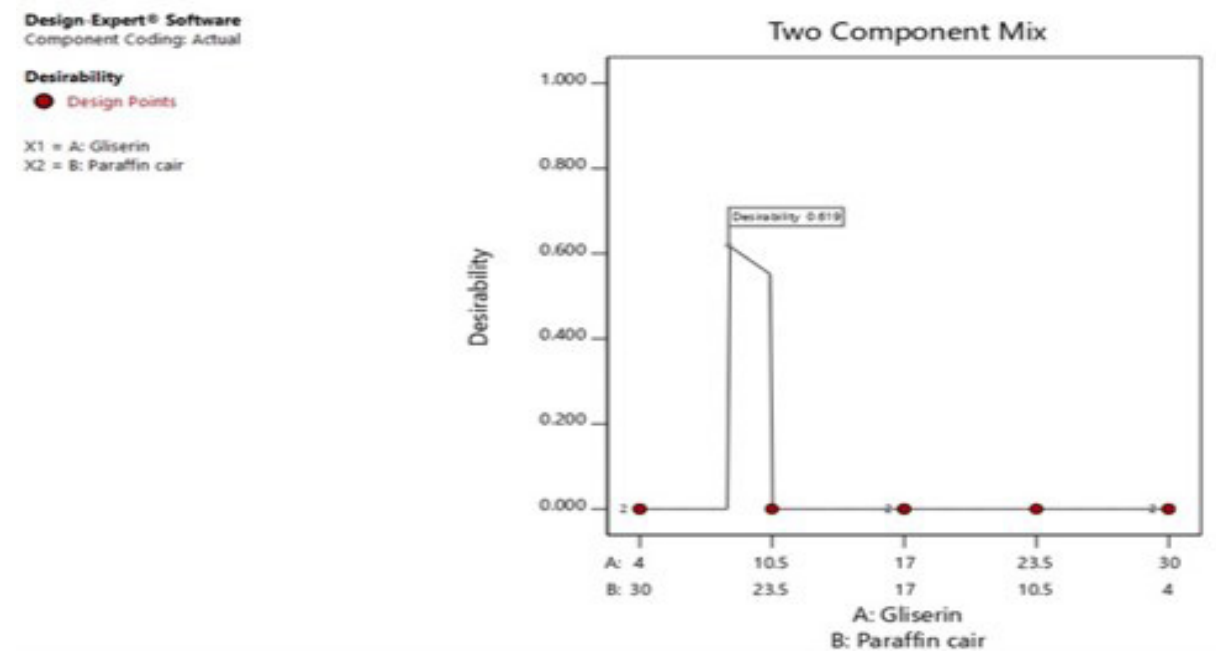

Gambar 2. Formula optimum F2 dengan nilai desirability 0,619 (Design Expert versi 11) 


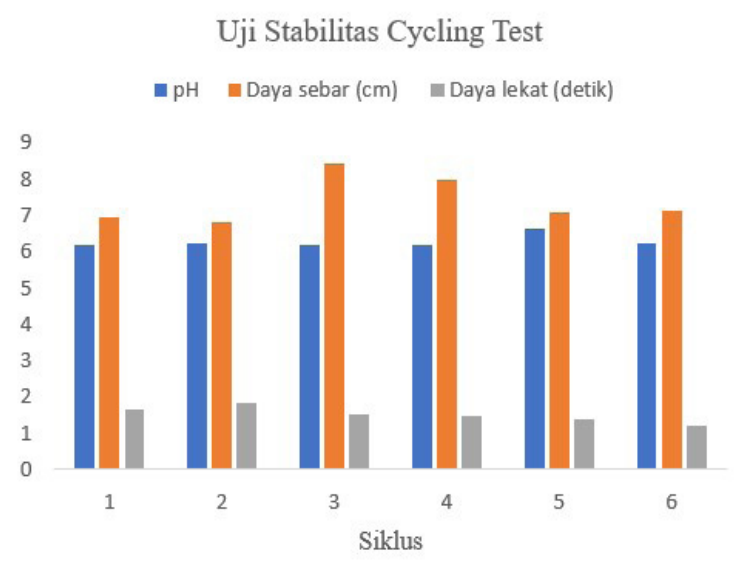

Gambar 3. Uji stabilitas fisik krim ekstrak kina $20 \%(\mathrm{pH}$, daya lekat dan daya sebar)
Uji Stabilitas Cycling Test

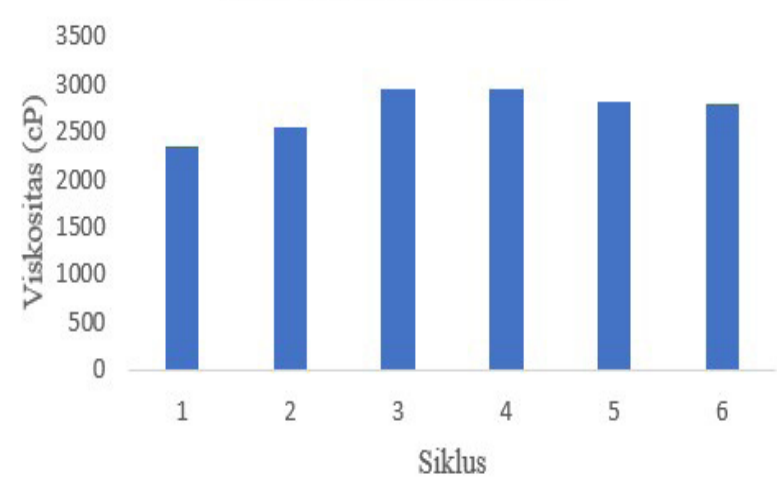

Gambar 4. Uji stabilitas fisik krim ekstrak kina $20 \%$ (viskositas)

\section{Uji aktivitas Krim ekstrak kina}

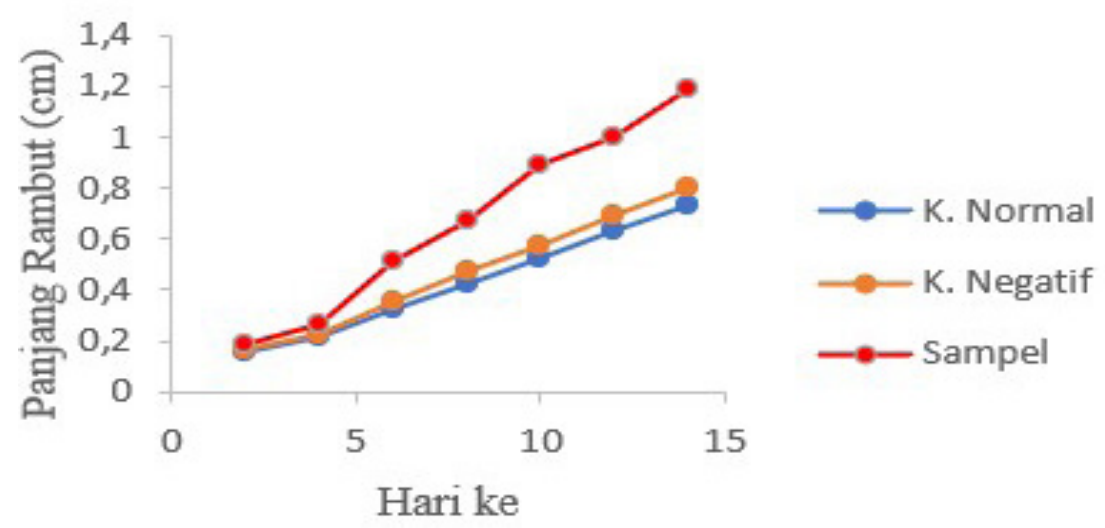

Gambar 5. Uji aktivitas krim ekstrak kina 20\% (panjang rambut)

area uji 122,91\% dari area kontrol normal dan $104,48 \%$ dari kontrol negatif $(p<0.05)$. Hal ini menunjukkan bahwa ekstrak kina dengan konsentrasi $20 \%$ berpotensi sebagai penyubur pertumbuhan rambut dengan mekanisme telangiektasis. ${ }^{1-4}$

Dari uji iritasi akut dermal sediaan krim ekstrak kulit kina 20\%, kontrol normal dan kontrol negatif memberikan indeks eritema dan udema 0. Hal ini menunjukkan bahwa bahan aktif ekstrak kina dan bahan tambahan yang digunakan dalam proses pembuatan krim bersifat non iritan sehingga relatif aman saat diaplikasikan ke permukaan kulit. ${ }^{15}$

\section{Simpulan}

Konsentrasi ekstrak kina yang memberikan aktivitas penyubur rambut optimum adalah 20\%. Sediaan krim F2 dengan konsentrasi ekstrak $20 \%$ dan variasi konsentrasi gliserin 10,5 dan paraffin cair $23,5 \%$ merupakan formula optimum yang memberikan kriteria/karakteristik sediaan akhir yang diinginkan (nilai desirability: 0,619), memiliki aktivitas, stabilitas fisik dan keamanan yang baik.

\section{Daftar Pustaka}

1. Suhery W.N., Febrina M., Permatasari I. Formulasi Mikroemulsi dari Kombinasi Minyak Kelapa Murni (Virgin Coconut Oil) dan Minyak Dedak Padi (Rice Bran Oil) Sebagai Penyubur Rambut. Traditional Medicine Journal. 2018. 23(1)

2. Satheeshan KN., Seema BR., dan Manjusha AV.M. Development and evaluation of VCO based herbal hair tonic. Journal of Pharmacognosy and Phytochemistry. 2020; 9(2): 485-493

3. Indriaty S., Sulastri L., Uji Aktivitas Ekstrak Air Akar Manis (Glycyrrhiza glabra L.) Sebagai Penyubur Rambut Pada Kelinci Jantan. Pharmacognosy and Natural Chemistry. 2016. Vol 1 (1) 
4. Tanaka, S., Saito, M., \& Tabata, M. Bioassay of crude drugs for hair growth promoting activity in mice by a new simple method. Planta Medica, 1980; 40 (Suppl.). https://doi.org/10.1055/s-2008-1075009

5. Artanti, N., Udin, L. Z., Hanafi, M., Jamilah, Kurniasih, I. R., Primahana, G., dkk. Bioactivities examination of Cinchona leaves ethanol extracts. AIP Conference Proceedings, 1803. 2017. https://doi.org/10.1063/1.4973144

6. Blume-Peytavi Ulrike, Varvar Kanti, and A. V. The Alopecias Diagnosis and Treatments (F. E. M. Bouhanna P.MD., and Bouhanna (ed.). CRC Press. 2016.

7. Gorzelanny, C., Mess, C., Schneider, S. W., Huck, V., \& Brandner, J. M. Skin barriers in dermal drug delivery: Which barriers have to be overcome and how can we measure them? In Pharmaceutics. 2020. Vol. 12, Issue 7. https://doi. org/10.3390/pharmaceutics12070684

8. Vitorino, C., Sousa, J., \& Pais, A. Overcoming the Skin Permeation Barrier: Challenges and Opportunities. Current Pharmaceutical Design. 2015. 21(20)

9. Mondong FR., Sangi MS., Kumaunang M. Skrining Fitokimia dan Uji Aktivitas Antioksidan Ekstrak Etanol Daun Patikan Emas (Euprorbia prunifolia Jacq.) dan Bawang Laut (Proiphys amboinensis (L.) Herb). Jurnal MIPA UNSRAT Online. 2015. 4 (1) 81-87.

10. Simões A., Veiga F., Vitorino C. Progressing Towards the Sustainable Development of Cream Formulations. Pharmaceutics. 2020. 12, 647; doi: 10.3390/pharmaceutics 12070647

11. Yoon, J.I. Hair Growth Promoting Effect of Zizyphus Jujuba Essential Oil. Journal Food and Chemical Toxicology. 2010. 1350-1354

12. Sulastri L., Indrawati T., Taurhesia S. Uji Aktivitas Penyubur Rambut Gel Kombinasi Ekstrak Air Teh Hijau Dan Herba Pegagan. Medical Sains. 2019. Vol. 4 No.1. 19-33

13. Manosroi, A., Kongkaneramit, L., \& Manosroi, J. Stability and transdermal absorption of topical amphotericin B liposome formulations. International Journal of Pharmaceutics. 2004. 270(1-2). $\quad \mathrm{https}: / /$ doi.org/10.1016/j. ijpharm.2003.10.031

14. Montenegro, L., Lai, F., Offerta, A., Sarpietro, M. G., Micicchè, L., Maccioni, A. M., dkk. From nanoemulsions to nanostructured lipid carriers: A relevant development in dermal delivery of drugs and cosmetics. Journal of Drug Delivery Science and Technology. 2016.32. https:// doi.org/10.1016/j.jddst.2015.10.003

15. BPOM. Peraturan Kepala Badan Pengawas Obat Dan Makanan Republik Indonesia Nomor 7 Tahun 2014 Tentang Pedoman Uji Toksisitas Nonklinik Secara In Vivo. 2014.

16. Rabima dan Marshall. Uji Stabilitas Formulasi Sediaan Krim Antioksidan Ekstrak Etanol 70\% Dari Biji Melinjo (Gnetum gnemon L.). Indonesian Natural Research Pharmaceutical Journal. 2017. 2 (1): 107-121. 